\title{
A Study on the Customer Satisfaction towards Online Shopping In Tirupati Town
}

\author{
Dr. A B Santhi \\ Principal, SGS UG \& PG Collge, Tirupati, Andhra Pradesh, India.
}

\begin{abstract}
This study titled "A Study on Customer Satisfaction towards Online Shopping in Tirupati Town" has been undertaken to understand the factors influencing customers' online shopping decisions and how these factors affect customer satisfaction. Descriptive Research Design has been used for this study. A well-structured questionnaire was designed and administered to collect samples across TirupatiTown. Due to the need for a variety of respondents who have had previous experience with online shopping, convinced sampling technique was chosen. The study has been undertaken with reference to a sample size of 120 respondents. After collecting the data, the data was classified, tabulated and codified. Necessary statistical tools such as Percentage Analysis and 't'tests has been used to interpret the data. The results of this study may be of great use to businesses which are looking to expand into or venture into the online shopping environment.
\end{abstract}

Keywords: Online Shopping, E-retailers,

\section{Introduction}

Retail is the sale of goods to end users, not for resale. The word retail is derived from the French word retailer, meaning to cut a piece off or to break bulk. In simple terms, it implies a first hand transaction with the customer. Retailing can be defined as the buying and selling of goods and services. It can also be defined as the timely delivery of goods and services demanded by consumers at prices that are competitive and affordable. (Ms.VidushiHanda, Mr.Navneet Grover) e-Commerce in India is booming now a days. According to a study conducted by Google India, there were 35 million online shoppers in India in 2014 and is expected to cross 100 million mark by the end of year 2016. Broadband internet and explosive growth of mobile phones are fuelling this growth further.

Companies like Flipkart have already crossed billion dollar valuation. If any one has a product to sell, this is perhaps the best time to start selling it through online. Here is an ultimate guide to teach the person how to sell online in India.

\section{Start Selling Online}

Amazon and flipkart start selling online in India or in any country for that matter involves various costs. It's important to find out first if any one can make good profits after considering all those costs. The following important costs are mentioned below:

Shipping Cost - Visit the nearest courier or shipping company and find out how much it would cost to ship the chosen product to various parts of India. Make a list of states and shipping fee. Normally this cost hovers from $5 \%$ to $15 \%$ of the product cost depending on the size and weight of the product.

Packaging Cost - Depending on the type of product, one who plans to sell, he/she needs to consider the packaging cost. Check the different packing material and calculate how much the person needs for one product. Calculate the total cost per product accordingly. Normally from $0.5 \%$ to $2 \%$ of the product cost.

Payment Gateway Cost : If you are planning to setup your own store, you will need a payment gateway. These sites normally charge from $1.5 \%$ to $3 \%$ of the total transaction. There could be one time setup fee and recurring annual maintenance fees. Last time it is noticed that, most payment gateway providers had waived off these fees. The seller can negotiate the transaction fee if it has higher volume.

Storage Cost - Depending on the product, it might need to rent warehouse or some storage space for the products. Find out this cost as well. Some online marketplaces like Amazon let customers use their warehouses at a small fee.

Marketing Cost - Like any other business, it will have to tell the world that have arrived. Surely, there are free ways to promote the business but at some point of time seller has invests in paid marketing channels. Google's AdWords is a good platform to start with online ads and it also offers tools to calculate the costs.

$A$ fair idea of different costs involved in selling online, you can do quick math to find out the profitability of your venture. Here is a simple formula :

Profit Margin $=$ Selling price $-($ Sourcing Cost + Packing \& Shipping + Transaction Fees + Marketing Cost + Variable Costs) 
The profit margin is positive, it is good for a company to go ahead and start selling online. If its very low or negative, it is better to think about minimising the costs.

\section{Background of the Online Shopping Malls}

Competing in a high-pressure business scenario has become a challenge for retailers. As an effective alternative sales channel sellers are looking at the internet, which gives them direct access to target customers. Online retailing (also known as e-retail) is a web-enabled interface between a retailer and its target consumers for selling products and services on the web with the facility of ecommerce. These kinds of retailers are also known as e-market. Almost all big retailers are now electronically present on the World Wide Web. The online shopping environment has gone through a lot of transformation and today it is still developing in a much diversified way. It has become very popular in the areas of apparel, arts and handicrafts, books, car rentals, computers and electronics, cosmetics, financial services, gifts and novelties, etc. Some of the major advantages of e-retailing which makes it popular among the retailers are: low investment cost, direct access to target customers, quick return on investment This kind of retail format helps the retailers to serve their customer quickly and more efficiently by offering them a detailed portfolio of products and services. On the other hand, availability of the point of transaction data helps the retailers to analyze and interpret their target customers. It has become the most efficient way to offer valuable information

It takes time for individuals to build up confidence to shop online. Initially shoppers may restrict themselves to searching for information or using e-mail. As their confidence grows their use of the Internet for purchase is likely to increase with a move to higher value items and more frequent purchases.

\section{Scope of the Study}

In India, the first time ever, shoppers are going to the web for most of their purchases has resulted in more and more retailers providing online avenues for customers to make purchases at the click of the mouse. Customers not only use the internet to make purchases but also to search for information about the product or service being purchased. Internet has changed the way of conducting business. Many businesses have started building up their strategies around the internet.

If E-Marketers analyze and understand the factors influencing Indian customers' online behavior, they can further fine-tune their business strategies towards customer preferences.

This study deals with the customers' perceptions towards the following aspects of online shopping and how the presence or lack of these aspects in an online shopping environment affects customer satisfaction.

$>$ Product categories that customers purchase online

> Quality \& availability of the product

$>$ Mode and Speed of delivery of the product

$>$ Product price / Offers provided for online shoppers

$>$ Payment options available for the customers

$>$ Shipping, Return and Exchange policies

$>$ Features of the shopping website such as

$>$ Design

$>$ Information provided

$>$ Accessibility

$>$ Ease of use

\section{Objectives Of The Study}

The primary objective of this study is to identify and understand the demographic factors affecting customer satisfaction with respect to in online shopping in India. The Secondary Objectives are:

- To analyse product categories for which customers favour online shopping and product categories for which they still abide by the traditional approach.

- To analyse features that customers expect at an online shopping portals.

- To analyse the different payment and delivery systems preferred by the customers.

- To analyse the inhibitions faced by customers during online purchases.

- To analyse how these factors interact to influence customer purchase decisions.

\section{Review of Literature}

Internet usage history and intensity also affect online shopping potential. Consumers with longer histories of Internet usage, educated and equipped with better skills and perceptions of the Web environment have significantly higher intensities of online shopping experiences and are better candidates to be captured in the well-known concept of flow in the cyber world (Hoffman and Novak, 1996;). Those consumers using the 
Internet for a longer time fromvarious locations and for a higher variety of services are considered to be more active users.

\section{Online Shopping Behavior}

Identifying pre-purchase intentions of consumersis the key to understand why they ultimately do or do not shop from the Web market. One stream of research under online consumer behavior consists of studies that handle the variables influencing these intentions. A compilation of some of the determinants researchers have examined are: transaction security, vendor quality, price considerations, information and service quality, system quality, privacy and security risks, trust, shopping enjoyment, valence of online shopping experience, and perceived product quality. Online shopping, referred to as online retailing or e-tailing, is growing every day in India. According to eBay India Census (2011) published on September 28th 2011 at Bangalore, Online Shopping is mainstream \& a nationwide phenomenon: India had over 3,311 e-commerce hubs across the country.

According to an article published in The Economic Times about an ASSOCHAM survey dated October 19th 2011, "Products like mobile phones, e-tablets, consumer electronics, gift articles, apparel and ornaments are the major attractions for consumers who shop online". One of the main reasons why customers prefer online shopping for such products is because of the large variety of these items available in the market. The websites enables customers to search and compare products with ease. Another important reason for the number of online shoppers to constantly multiply is because of 24X7 shopping advantage and the home delivery of products. Shopping websites also provide discounts, vouchers and free gifts to attract customers.

Electronic Commerce: A Managerial Perspective, Turban et al. has provided a consumer behaviour model in E-Commerce environment. This model categorizes the factors that influence the customers' buying decisions into the following categories.

$>$ Independent Variables

$>$ Intervening or Moderating Variables

$>$ Decision Making Process

$>$ Dependent Variables

The different categories of products that customers are willing to purchase online depend upon the customer perception of risk. Customers perceive a higher degree of risk if the product category is new, or if the perceived value of the product is high. Shiffman et al. in his book Consumer behavior states that "Studies also found that perceptions of trust and risk were the major determinants' of consumers' attitudes toward shopping online and that trust reduced consumers' perceived risk in the electronic marketplace".

\section{Consumer Satisfaction and Loyalty in the Online Market}

Investing in consumer satisfaction from the online experience and creating brand or site loyalty are critically important for companies that want to have a long run presence on the Web. There are two approaches taken to induce loyalty into consumers in an online context.

One approach is to focus on concrete factors. For example, creating a convenient and well-designed online store and offering secure transactions are the keystones of satisfying e-consumers. However, all satisfied consumers do not become loyal. Personalization attempts and increasing the social value of online experiences are very important to make consumers build strong brand relationships in the cyber world. Although the argue the opposite, some studies find that personalized Web sites and customer communities are highly influential on the consumer brand relationship especially for experienced Internet consumers. Besides, businesses that can create trust and increase the perceived value of online shopping can turn their satisfied consumers into loyal ones in the e-marketing environment, too. The online environment accommodates so many opportunities for creating loyalty that even offline offerings can be effectively facilitated with supporting after sale services provided through the Web.

\section{Research Methodology}

Descriptive research design was employed in this study to describe customer expectations, influencing variables etc. In Tirupati town there are maximum people using online shopping sites for purchasing products. These customers constitute the study population. In the present study 120 online shopping customers of Flipkart and Amazon only. My research confined to top two online shopping companies based in tirupati constitutes the sample. Convenience sampling technique is used for collected by administering a structured questionnaire to consumers who use online for shopping. The questionnaire was circulated in google forms and was completed by the sample respondents. 


\section{Results And Discussion}

Most of the sample respondents use the Internet for more than 6 hours per day (58\%) for different age groups. The most popular activities for which the respondents use the Internet (based on percentage of responses) are: Browsing, Shopping, Banking, Chatting, Social Networking. A large percentage of the respondents $(85 \%)$ use the Internet for information search prior to making purchase decisions. The products that the respondents often purchase online (based on percentage of responses) are Train / Flight Tickets, Movie / Event Tickets, Books / CDs. Features of shopping portals that the respondents consider most important (based on percentage of responses) are: Payment Options, Product Variety / Availability, Speed \& Quality of Delivery, Security and User Friendly Presentation.

Most preferred payment options of the respondents are Cash on Delivery and Internet Banking. Factors that annoy customers the most (based on percentage of responses) while shopping online are failed transactions and insecure payment options. Most frequented shopping portals in India (based on percentage of responses) are; IRCTC, Flip kart and Amazon. Majority of the customers are willing to spend more than Rs.10000 for a single online purchase (50\%). Almost all the respondents (90\%) agree that online shopping helps save time and is convenient. Majority of the respondents agree that it is easier to search for and compare products online. $41 \%$ of the respondents believe that online shopping will supersede traditional shopping eventually. Frequency of shopping online is independent of respondents' gender. $60 \%$ of the respondents expect discounts and better deals while shopping online when compared to what is offered at traditional stores. $43 \%$ of the respondents hesitate to give out debit / credit card information due to privacy and security issues.

\section{Conclusions And Summary}

The findings and results reflect the perceptions, preferences and factors influencing satisfaction of online shoppers in Tirupati Town. The results indicate that the respondents are becoming more internet savvy every day. As they become more confident they are ready to buy high value products online as well. Businesses venturing into or expanding into the online market need to reduce the customer perceived risks by making shopping portals easier to navigate, providing secure payment options as per norms, ensuring speed and quality of delivery to gain and maintain customer trust, better presentation and categorization to make up for the missing touch and feel experience etc. Efforts need to be taken to educate the online buyers on the steps that need to be undertaken while making an online purchase. Moreover, the feedback of an online buyer should be captured to identify flaws in service delivery. This can be done through online communities and blogs that serve as advertising and marketing tools and a source of feedback for enterprises.

\section{Reference}

[1] Ms.VidushiHanda, Mr.Navneet Grover, Retail Sector in India: Issues and Challenges, International Journal of Multidisciplinary Research, Vol. 2 Issue 5, May 2012.

[2] Hoffman, D.L. and Novak, T.P. (1996), "Marketing in hypermedia computer-mediatedenvironments: conceptual foundations",Journal of MarketingVol. 60 No. 3,pp. 50-68.

[3] http://timesofindia.indiatimes.com/business/india-business/Online-retail-industry-to-touch-Rs-7000-crore-

by2015/articleshow/9085342.cms. http://timesofindia.indiatimes.com/business/india-business/Online-retail-industryto-touch-Rs7000-crore-by-2015/articleshow/9085342.cms

[4] http://articles.economictimes.indiatimes.com/2011-10-19/news/30297594_1_online-shopping-e-shoppingassochamsurveyhttp://articles.economictimes.indiatimes.com/2011-10-19/news/30297594_1_online-shopping-eshopping-assocham-survey.

[5] http://articles.economictimes.indiatimes.com/2012-02-05/news/31027081_1_online-shopping-metros-ecommerce

[6] http://articles.economictimes.indiatimes.com/2012-02-05/news/31027081_1_online-shopping-metros-ecommerce

[7] http://www.fibre2fashion.com/industry-article/37/3677/evolution-of-online-eretaill.asphttp://www.fibre2fashion.com/industryarticle/37/3677/evolution-of-online-retail1.asp

[8] http://www.fibre2fashion.com/industry-article/37/3677/evolution-of-online-retail1.asp

[9] http://www.fibre2fashion.com/industry-article/36/3677/evolution-of-online-retaill.asp

[10] http://www.fibre2fashion.com/industry-article/35/3677/evolution-of-online-retaill.asp

[11] http://www.fibre2fashion.com/industry-article/34/3677/evolution-of-online-retaill.asp

[12] http://www.fibre2fashion.com/industry-article/38/3677/evolution-of-online-retail1.asp

Annexure - I

Table: 1 Internet Proficiency and age wise classification of sample respondents

\begin{tabular}{|c|c|c|c|c|c|}
\hline \multirow[t]{2}{*}{ Internet Proficiency } & \multicolumn{4}{|c|}{ Age Group } & \multirow{2}{*}{$\begin{array}{l}\text { Total } \\
(\mathrm{N}=120)\end{array}$} \\
\hline & 20-30 & $31-40$ & $41-50$ & 51 \& Above & \\
\hline Beginner & $\begin{array}{c}11 \\
(25.6)\end{array}$ & $\begin{array}{c}9 \\
(45.0)\end{array}$ & $\begin{array}{c}17 \\
(47.2)\end{array}$ & $\begin{array}{c}5 \\
(23.8)\end{array}$ & $\begin{array}{c}42 \\
(35.0)\end{array}$ \\
\hline Intermediate & $\begin{array}{c}17 \\
(39.5)\end{array}$ & $\begin{array}{c}7 \\
(35.0)\end{array}$ & $\begin{array}{c}12 \\
(33.3)\end{array}$ & $\begin{array}{c}3 \\
(14.3)\end{array}$ & $\begin{array}{c}39 \\
(32.5)\end{array}$ \\
\hline Experienced & $\begin{array}{c}15 \\
(34.9) \\
\end{array}$ & $\begin{array}{c}4 \\
(20.0) \\
\end{array}$ & $\begin{array}{c}7 \\
(19.4) \\
\end{array}$ & $\begin{array}{c}13 \\
(61.9) \\
\end{array}$ & $\begin{array}{c}39 \\
(32.5) \\
\end{array}$ \\
\hline Total & $\begin{array}{c}43 \\
(100) \\
\end{array}$ & $\begin{array}{c}20 \\
(100)\end{array}$ & $\begin{array}{c}36 \\
(100) \\
\end{array}$ & $\begin{array}{c}21 \\
(100) \\
\end{array}$ & $\begin{array}{c}120 \\
(100)\end{array}$ \\
\hline Chi-square & \multicolumn{5}{|c|}{$\chi 2=15.305^{*} ; \quad(\mathrm{p}=0.018) \mathrm{df}=6$} \\
\hline
\end{tabular}


Since the calculated value is less than the table value, therefore there is systematic association between internet proficiency and age wise.

Table: 2 Gender and the frequency of online shopping of sample respondents

\begin{tabular}{|c|c|c|c|c|c|}
\hline \multirow{2}{*}{ Gender } & \multicolumn{4}{|c|}{ Online shopping } & \multirow{2}{*}{$\begin{array}{l}\text { Total } \\
(\mathrm{N}=120)\end{array}$} \\
\hline & Frequently & Often & sometimes & Rarely & \\
\hline Male & $\begin{array}{c}17 \\
(25.6) \\
\end{array}$ & $\begin{array}{c}18 \\
(45.0) \\
\end{array}$ & $\begin{array}{c}12 \\
(47.2) \\
\end{array}$ & $\begin{array}{c}7 \\
(22.6) \\
\end{array}$ & $\begin{array}{c}54 \\
(45.0)\end{array}$ \\
\hline Female & $\begin{array}{c}16 \\
(39.5)\end{array}$ & $\begin{array}{c}13 \\
(35.0)\end{array}$ & $\begin{array}{c}13 \\
(33.3)\end{array}$ & $\begin{array}{c}24 \\
(77.4)\end{array}$ & $\begin{array}{c}66 \\
(55.5)\end{array}$ \\
\hline Total & $\begin{array}{c}33 \\
(100) \\
\end{array}$ & $\begin{array}{c}31 \\
(100)\end{array}$ & $\begin{array}{c}25 \\
(100)\end{array}$ & $\begin{array}{c}31 \\
(100)\end{array}$ & $\begin{array}{c}120 \\
(100)\end{array}$ \\
\hline Chi-square & \multicolumn{5}{|c|}{$=0.028) \mathrm{df}=3$} \\
\hline
\end{tabular}

Since the table value is less than the calculated value at $95 \%$ confidence. Therefore there is systematic association between gender and the frequency of online shopping. As in our sample we do not consider respondents who never use online shopping. So we are excluding the 'Never' column from our analysis.

Table :3 Age and the frequency of online shopping of sample respondents

\begin{tabular}{|c|c|c|c|c|c|}
\hline \multirow[t]{2}{*}{ Age Group } & \multicolumn{4}{|c|}{ Online shopping } & \multirow{2}{*}{$\begin{array}{l}\text { Total } \\
(\mathrm{N}=120)\end{array}$} \\
\hline & Frequently & Often & sometimes & Rarely & \\
\hline $20-30$ & $\begin{array}{c}15 \\
(45.5)\end{array}$ & $\begin{array}{c}13 \\
(41.9)\end{array}$ & $\begin{array}{c}16 \\
(64.0)\end{array}$ & $\begin{array}{c}9 \\
(29.0)\end{array}$ & $\begin{array}{c}53 \\
(44.2)\end{array}$ \\
\hline $31-40$ & $\begin{array}{c}7 \\
(21.2)\end{array}$ & $\begin{array}{c}6 \\
(19.4)\end{array}$ & $\begin{array}{c}6 \\
(24.0)\end{array}$ & $\begin{array}{c}5 \\
(16.1)\end{array}$ & $\begin{array}{c}24 \\
(20.0)\end{array}$ \\
\hline $41-50$ & $\begin{array}{c}6 \\
(18.2)\end{array}$ & $\begin{array}{c}9 \\
(29.0)\end{array}$ & $\begin{array}{c}3 \\
(12.0)\end{array}$ & $\begin{array}{c}7 \\
(22.6)\end{array}$ & $\begin{array}{c}25 \\
(20.8)\end{array}$ \\
\hline $51 \&$ Above & $\begin{array}{c}5 \\
(15.2) \\
\end{array}$ & $\begin{array}{c}3 \\
(9.7)\end{array}$ & $\begin{array}{c}0 \\
(0.0)\end{array}$ & $\begin{array}{c}10 \\
(32.3) \\
\end{array}$ & $\begin{array}{c}18 \\
(15.0) \\
\end{array}$ \\
\hline Total & $\begin{array}{c}33 \\
(100) \\
\end{array}$ & $\begin{array}{c}31 \\
(100) \\
\end{array}$ & $\begin{array}{c}25 \\
(100) \\
\end{array}$ & $\begin{array}{c}31 \\
(100)\end{array}$ & $\begin{array}{c}120 \\
(100) \\
\end{array}$ \\
\hline Chi-square & \multicolumn{5}{|c|}{$\chi^{2}=16.929 * ; \quad(\mathrm{p}=0.0498) \mathrm{df}=9$} \\
\hline
\end{tabular}

The critical value $\chi 2$ at 0.05 level of significance from the table is 16.929 for degree of freedom 9.Since the calculated value is less than the table value, Therefore there is association between Age group and the frequency of online shopping. As in our sample we do not consider respondents who never use online shopping. So we are excluding the 'Never' column from our analysis.

Table :4 Income and payment mode of sample respondents

\begin{tabular}{|c|c|c|c|c|c|}
\hline \multirow[t]{2}{*}{ Income levels. } & \multicolumn{4}{|c|}{ Payment mode } & \multirow{2}{*}{$\begin{array}{l}\text { Total } \\
(\mathrm{N}=120)\end{array}$} \\
\hline & $\begin{array}{ll}\text { Cash } & \text { On } \\
\text { Delivery } & \end{array}$ & Debit card & Credit card & $\begin{array}{l}\text { Net } \\
\text { Banking }\end{array}$ & \\
\hline Dependent & 3 & 2 & 1 & 9 & 15 \\
\hline Less than1 lakh & 8 & 11 & 9 & 6 & 34 \\
\hline $1-2$ Lakhs & 7 & 8 & 5 & 6 & 26 \\
\hline $2-5$ Lakhs & 6 & 13 & 3 & 7 & 29 \\
\hline More than 5 lakhs & 3 & 8 & 5 & 0 & 16 \\
\hline Total & 27 & 42 & 23 & 28 & 120 \\
\hline Chi-square & \multicolumn{5}{|c|}{$\chi 2=21.889^{*} ; \quad(p=0.0387) d f=12$} \\
\hline
\end{tabular}

Since the table value is less than the calculated value, Therefore there is systematic association between annual income and the payment options. 